\title{
The Implementation of the National Minimum Wages in Malaysia
}

\author{
N. A. Ibrahim and R. Said
}

\begin{abstract}
Malaysia's national minimum wages were announced on 30 April 2012, and are enforced in stages. The Minimum Wage Order 2012 was gazetted on 16 July, 2012 which enforce the implementation of the minimum wage rates on 1 January, 2013 for employers with more than five workers and on 1 July, 2013 for employers employing five and less workers, excluding firms that provide professional services classified under the Malaysian Standard Classification of Occupation (MASCO). Despite the fact that the real labour productivity of Malaysia grew faster at 6.7 per cent between 2000 and 2008 compared to a mere 2.6 per cent increase in average wages, many employers still object to its implementation. This paper shed more light to the concept behind a statutory minimum wage policy and its application in the case of Malaysia. Its rationale and justification are reviewed and analysed. The objectives determined the dimensions, coverage and criteria considered in setting the minimum wages. The objectives of a minimum wages policy include addressing efficiency issues in labour markets, promoting productivity growth and reducing poverty or inequality. While the Malaysian government's concern to improve the living standards of the poor and vulnerable is valid and merit serious attention, it is not the most appropriate instrument to address poverty and inequality. Besides that, many of the poor people are unemployed or employed in the informal sector where wages are not binding. Hence, the main justification for introducing and implementing a minimum wage policy in Malaysia would be to address inefficiencies in the labour markets that preclude competition, which can lead to the suppression of wages, especially the low-skilled and low-income workers. Comparisons are made among countries that have implemented the statutory minimum wages policy. This will help many to understand the common and different features that Malaysia has with them.
\end{abstract}

Index Terms-Minimum wages, concept, justification, Malaysia.

\section{INTRODUCTION}

Whether to adopt a statutory minimum wage has been debated in Malaysia for a number of years, even after the enactment of the National Wages Consultative Act 2011. Part of the motivation behind this debate was the slow growth of wages relative to labour productivity growth. The real labour productivity of Malaysia grew faster at 6.7 per cent between 2000 and 2008 compared to a mere 2.6 per cent increase in average wages. Another motivation is to have growth with inclusiveness. In the New Economic Model, the government envisioned our country to be a high income economy and

Manuscript received September 9, 2013; revised November 12, 2013.

N. A. Ibrahim is with the Department of Economics, Faculty of Business Management, Universiti Teknologi MARA Malaysia (e-mail:

R. Said is with the Faculty of Economics and Management, Universiti Putra Malaysia (e-mail: rus@econ.upm.edu.my). enable all communities to fully benefit from the wealth of the country. In achieving these goals, the government has to ensure that the low income people are not left out in reaping the benefits of growth and enjoying better quality of life.

Income growth among the top 20 percent income earners has been strong; however, the income of the bottom 40 percent was rather stagnant. About 33 percent ( 3.2 million) of workers in the private sector are earning less than RM700 a month in 2010 and below the poverty line income of RM763 a month (for Peninsular Malaysia in 2009). If our country is to become a high income economy with inclusiveness, therefore, suppressed wages among the low income need to be corrected. There is a need to reduce our dependence on cheap labour towards a more efficient and productive labour market.

The International Labour Organisation has defined minimum wages as the lowest basic wage guaranteed by law as an attempt to put a floor under the wages of a particular subgroup of the working population, that is, the working poor. In Article 7 of the ILO Convention no 131 on minimum wage fixing (1970) and its accompanying recommendation no 135 , specify that the minimum wage should not be fixed at a lower rate than one which would ensure the subsistence of the worker and his or her family. Before the implementation of the national minimum wage, Malaysia did not ratify to this convention.

\section{RAtionale FOR A Minimum Wage Policy}

Worldwide evidence shows that even though a well implemented minimum wage that imposes a moderate and economically reasonable level can have positive impacts on the welfare of the low income workers, it is not the appropriate instrument to address poverty and inequality. In this case if implemented correctly, and set at the right level, minimum wages can increase wages without reducing employment levels. [1] argue that minimum wages can increase employment in New Jersey. They evaluate the impact of minimum wage law that was implemented in New Jersey in year 1992 and present new evidence on the effect of minimum wages on establishment-level employment outcomes. Due to New Jersey is relatively a small economy that is closely linked to nearby states, the authors use a control group of fast food restaurants in Pennsylvania for comparison. The researchers conduct a survey on fast food restaurants located in New Jersey and eastern Pennsylvania The authors found no evidence that the increase in New Jersey's minimum wage reduced employment at fast food restaurants in the state. This finding is consistent with a growing number of studies. In fact, the study finds a slight increase in employment after the minimum wage law is 
implemented. In addition, the results are also unable to show that increase in minimum wage would reduce the opening of new fast food outlets in the state. In conclusion, they conclude that the prices of fast food meals increased in New Jersey relative to Pennsylvania after the increase of minimum wage. This finding implies that the burden of rise in wages was passed to consumers. However, there is no evidence showing significant price difference among the restaurants within New Jersey.

Currently the demand for foreign workers dramatically increased to nearly 3 million in 2010 . Hence minimum wages also aims to balance the demand for local workers. With the pressure of additional cost of having foreign workers such as levy, medical expenses, accommodation and insurance, employer will favour local workers.

Malaysian Government is really concerned to improve the circumstances of the working poor and unequal distribution of income. Since 1971, the government has implemented the New Economic Policy (NEP) with the aim of promoting national unity through the eradication of poverty and restructuring of the society. To date, Government Transformation Program under the New Economic Model has focused on raising the living standard of low income household as one of its National Key Results Area and has achieved great strides of reducing the disparity between the economical advantaged and the disadvantaged. In line with the national mission of becoming a developed nation in 2020 , the portion of the low income group needs to be reduced to 43 per cent from 57 percent in 2010. Hence, one of the goals of the national minimum wage policy is to raise the income of working poor. Although some families gain and others lose, the net trade-offs created by minimum wages hopefully will contribute to the growth of our economy.

In a study by [2] that used matched CPS surveys, found that over a 1-to-2 year period, minimum wages increase both the probability that poor families escape poverty line and the probability that non-poor families become poor, but the latter is dominant although it is statistically insignificant. Besides that, minimum wages tend to increase the incomes of poor families that are still remain below the poverty line. On the other hand, [3] found no compelling evidence to support the view that minimum wages help in poverty alleviation. Since both effects of wage increases and unemployment are concentrated among low-income groups, so income is redistributed among the low-income families rather than from the high- to low-income families. Thus, it is difficult to make a distributional or equity argument for minimum wages.

Another reason is to promote productivity growth. Minimum wages would give firms an incentive to increase their productivity. Increase in labour cost will increase companies operating costs. Although some firms might react to this increase by reducing redundant expenditures and increasing their efficiency, others might simply see their profits fall or go out of business. If the resources are liberated by the disappearance of less productive firms cannot easily be acquired by new and more productive firms, then the total output of the economy will suffer and the country may find itself further from its goal than before the minimum wage was introduced. [4] and [5] found that minimum wages will increase workers' productivity. This may be due to increased work effort, multitasking, reduce job turn over and more job training in order to enhance the labour capability.

\section{OBJeCtives of Minimum Wage Policy}

Many countries aim to achieve a number of objectives through their legislated minimum wages, but frequently not all of these goals are equally valid. Although their motivations differ from country to country, generally, there are three common goals that can be identified. They are:

1) Reducing poverty or inequality by increasing the wages of low-income workers,

2) Promoting productivity growth, and

3) Addressing efficiency issues in labour markets that reduce employment and increase profits at the expense of workers.

The Malaysian Minimum Wage Policy is not much different. In its first report [6] presented to the government in March 2012, the National Wages Consultative Council outlined the following objectives:

1) Ensuring the basic needs of workers and their families are met,

2) Providing sufficient social protection to workers,

3) Encouraging industry to move up the value chain by investing in higher technology and increase labour productivity, and

4) Reducing the nation's dependence on unskilled foreign labour.

The objective to reduce poverty and inequality is often argued as a tool to increase the income of the low-income workers. While the Malaysian government's concern to improve the living standards of the poor and vulnerable is valid and merit serious attention, it is not the most appropriate instrument to address poverty and inequality. Besides that, many of the poor people are unemployed or employed in the informal sector where wages are not binding. Hence, the main justification for introducing and implementing a minimum wage policy in Malaysia would be to address inefficiencies in the labour markets that preclude competition, which can lead to the suppression of wages, especially the low-skilled and low-income workers. Besides that, high wages tend to encourage high productivity, attract more locals into the labour force and therefore reduce the number of foreign workers.

\section{LITERATURE REVIEW}

Most studies isolate the impact of minimum wage by comparing changes in employment. The effects in agriculture sector for example documented in [7] and [8], tend to support the competitive hypothesis which is the minimum wages tend to have adverse impact on employment. [9] analyses the impact on unemployment, the correlation is highly related but not solely dependent on the efficiency and distributional but the enforcement factor is considered as very important element. Therefore one should not judge the net effect of minimum wage by simply looking at the employment status. Probation period is considered as main element too. [10] found extended minimum wage coverage account for 65 percent of the decline in peak-month cotton farming jobs 
between 1967 and 1969. Different age groups may be affected differently by the minimum wages. [11] for example, found that for a group of workers aged 16 to 19 , a $10 \%$ increase in the minimum wage reduces their employment by $1-3 \%$ in time series analyses and $0-3 \%$ in cross-sectional studies. For a group of workers aged 20 to 24 , the minimum wage has negative effects on them, however, the effects are relatively smaller than the teenage group. For the adult group, the effect of minimum wage is inconclusive as about half of this age group is already in the labour force.

\section{JUSTIFICATION FOR A Minimum WaGe POLICY}

Although it is impossible to establish the existence of monopsony power in Malaysia, there are several pieces of descriptive evidence that workers may not be recovering a fair share of their productivity through wages. [12] proved that minimum wage will reduce employment in the monopsony case. Minimum wages will make the employer price taker up to the level of employment. A simulation done by World Bank [13] suggests that monopsony power might not be serious issues because hourly rates tend to be highly correlated with productivity. There are some states where wages are lower than would be expected given the level of productivity such as in Putrajaya, Selangor and Malacca. In Malaysia, productivity does not depend on states and firms, so an alternative way to consider the relationship between wages and productivity is by looking across sectors. There are clear sector such as logistic, distributive trade, and especially agriculture, fishing and forestry in which workers earn less than would be expected given the productivity of formal firms in that sector. This situation implies that Malaysia only needs one national minimum wages policy to avoid regional biasness.

Different geographical area would result in different technology and productivity level. Workers in Sarawak earn roughly 20 per cent less than those in Peninsular Malaysia and those in Sabah and Labuan earn roughly 26 percent less. After considering other factors such as average wages, poverty line income, productivity growth, consumer price index and unemployment rate, the calculation for minimum wage rate for Peninsular Malaysia is RM900, which is much higher than the rate in Sabah and Sarawak which are RM770 and RM780 respectively.

Social security and lack of adequate saving are seems to happen in monopsony power. Productive sectors may lack bargaining power because the relationship between formality and productivity across sectors seems to be insignificant. In some cases, employers are unlikely to pay statuary wage rates to workers whom they are not declared to the EPF and SOCSO. If this situation happen, minimum wage is unlikely have positive impact.

\section{LEGISLATION}

Before the National Minimum Wages Consultative Council Act 2011 (Act 732) was enacted, the Wages Councils Act 1947 (Act 195) governed the provisions of minimum wages in Malaysia. The wage councils were established to fix legal minimum wages for certain categories of occupations or industries as recommended by the Commissions of Inquiry (COIs). Several wages regulation orders were gazetted to set the minimum wages for occupations like shop assistants, workers at ports, hotels and food catering, and security guards. With merely 7 percent of employed workers affected by the collective agreements, wages in Malaysia are largely determined by the market forces. Furthermore, the Wage Councils Act lacked the framework to enforce compliance and continuously review the minimum wages rates, hence defeating the purpose of having the minimum wages in the first place.

The National Wages Consultative Council Act 2011 (NWCC Act 2011) was gazetted on 15 September 2011 and the National Wages Consultative Council was established soon after that. The NWCC Act 2011 contains provisions on matters relating to the establishment of the NWCC, minimum wage order, investigation and enforcement, offences and penalties and other general matters. On 30 April 2012, the Prime Minister announced the implementation of the Minimum Wage Policy followed by the Minimum Wage Order 2012 gazetted on 16 July 2012. Under the provisions of the Minimum Wage Order 2012, the minimum wage is enforced from 1 January 2013 for employers with 6 employees or more, whereas those with 5 workers and below will be enforced from 1 July 2013. For those companies that may have constraints to implement the minimum wages, may apply for deferment. In the case of companies with 6 employees or more, there were more than 4,000 applications for deferment and they were granted 3 to 9 months deferment period, depending on their case.

\section{COVERAGE}

Malaysia has three distinct regional labour markets Peninsular Malaysia, Sarawak and Sabah (and Labuan). Therefore, there are economic justifications for considering a regional adjustment. This regional adjustment should be based on the ability of firms to pay, which is determined by their labour productivity in each region rather than the cost of living. However, the increase in wages for the low income earners have long been suppressed despite significant increases in the wages of the middle and high income earners. With persistent poverty rates, our government is concerned to improve the living standards of the poor and vulnerable, hence making the cost of living, which is indicated by the poverty line income, one of the two main considerations in determining the minimum wages in Malaysia.

Despite the demand for a multiple minimum wage levels particularly from the employers, evidence from around the world shows that this can lead to negative consequences because of the difficulty in enforcing the law, ensuring compliance and the possibility of further exacerbating market distortions. Higher minimum wages will attract workers from sectors and regions that have lower minimum wages. The sectors and regions with lower minimum wages will suffer from shortage of workers and therefore face potential decline in their contribution to GDP. Consequently, in the countries that are studied, there is a general trend of moving away from differentiating wage levels by occupation, sector and geography, towards having just one national level of the minimum wage. 
Most countries set one national level minimum wage and allow for a few exceptions or reductions, such as younger employees, disabled workers and apprentices. The reductions are granted mainly due to the low-productivity of workers whose employment opportunities become extremely limited when the minimum wage is set at a reasonably high level. Foreign workers are not given this reduction because such reduction would encourage more employment of the foreign workers at the expense of the local workers. Furthermore, it has been stipulated in Article 6 of International Labour Organisation convention 97 that there should be no discrimination in terms of conditions of employment, including wages, shall be placed on workers based on their nationality.

\section{CRITERIA FOR SETTING THE Minimum WAGE}

The National Wages Consultative Council (NWCC) deliberates on the minimum wage adjustments, which should rely on technical inputs and evidences in its decision-making. The formula to propose the minimum wage should consider important variables that justify the need of a minimum wage. The common criteria that many countries consider in implementing their minimum wages are:

- Labour productivity

- Competitiveness

- Unemployment

- GDP growth

- Consumer price index

- Cost of living

- Wages level.

As some of the criteria may overlap with each other, some countries may have some of these criteria whereas the rest may have others. It depends on their objectives. Malaysia, for instance, uses PLI per worker as an indicator for the cost of living above poverty level, and median wage as the firms' ability to pay. The median wage reflects the wages earned by the bottom half of wage earners in the private sector. These two variables become the base criteria in formulating the minimum wages. Besides that, the rates are adjusted with percentage change in labour productivity and consumer price index, and the differences between the regional unemployment rate and the natural unemployment rate of $4 \%$. The base criteria are averaged to represent the floor wage.

The minimum wage formula [6] is specified as follows:

$$
\begin{aligned}
& \text { Base criteria } M W_{i}=\operatorname{Avg}\left(\frac{P L I_{i}}{\text { Avg workers per house hold }}+\right. \\
& \text { Median wage } \left.{ }_{i}\right) X \\
& {\left[1+\left(\frac{P_{i}}{100}\right)+\left(\frac{C P I_{i}}{100}\right)-\left(\frac{U E_{i}}{100}\right)\right] \text { Adjustment criteria }}
\end{aligned}
$$

$$
\text { where }
$$

$M W=$ Minimum wage in $\mathrm{RM}$

$P L I=$ Poverty line income $(\mathrm{RM})$

$P=$ Productivity growth $(\%)$

$C P I=\%$ change in consumer price index

$U E=$ Real unemployment rate $(\%)$ : Actual unemployment rate minus natural unemployment rate $(4 \%)$

$i=$ Region

In the base criteria, PLI is divided by the average workers per household because the PLI is specified as the household average gross monthly income with more than one person working per household. Minimum wage, on the other hand, is specified as per worker. Adjustment has to be made so that they are comparable as per worker. The average workers per household are focused on the lowest $40 \%$ household income which is 1.2 persons per household. Care was taken to not average the number of workers for all households in the country as the higher income households tend to have more working person living in the house. This would not reflect the true value for the relatively poor households.

To align the minimum wage with the labour productivity growth, the floor wage needs to be adjusted with the percentage change in labour productivity. The percentage change in the general price level is captured in CPI. Unemployment rate is also included but it cannot be taken as the actual unemployment rate of each region due to the natural rate of unemployment. If a region has more than $4 \%$ unemployment, indicating a loose labour market, the floor wage will be adjusted downwards to reduce the impact of the implementation of minimum wage on its unemployment rate. However, if a region has less than $4 \%$ unemployment rate, indicating a tight labour market, it will be adjusted upwards to attract more locals into the labour force.

To identify the ideal minimum wage rate for each region, (1) is calculated with indicators prevalent to the respective regions for 2010. The proposed minimum wage rates for Peninsular Malaysia, Sabah and Sarawak are illustrated in (2), (3) and (4) respectively, below.

Peninsular Malaysia

$$
\begin{aligned}
& M W_{P M}=\frac{\left(\frac{763}{1.2}+1134.25\right)}{2} X[1+(0.038)+(0.032) \\
& =R M 956.73
\end{aligned}
$$

Sabah

$$
\begin{aligned}
M W_{S b h} & =\frac{\left(\frac{1048}{1.2}+577.40\right)}{2} X[1+(0.052)+(0.028) \\
& =R M 771.79
\end{aligned}
$$

Sarawak

$$
\begin{aligned}
M W_{S w k} & =\frac{\left(\frac{912}{1.2}+738.71\right)}{2} X[1+(0.036)+(0.027) \\
= & R M 781.58
\end{aligned}
$$

The proposed minimum wage rate for Peninsular Malaysia is RM956.73 is much higher than Sabah, which is RM771.79, and Sarawak RM781.58. This is mainly attributed to a higher median wage for Peninsular Malaysia. Sabah has the highest PLI, however, its median is the lowest. Sarawak, on the other hand, has moderate PLI and median wage. The Sarawak proposed minimum wage rate is slightly higher than the Sabah minimum wage rate. These rates were proposed by the National Wages Consultative Technical Committee and deliberated extensively by the NWCC, approved by the Minister of Human Resources and finally the Cabinet.

The final and approved minimum wage rates were 
announced by Malaysia Prime Minister, Dato' Sri Mohd Najib Tun Abdul Razak, on 30 April, 2012, as shown in Table I.

TABLE I: Minimum WAge RATES FOR PENinsular MALAysia, SARAWAK AND SABAH

\begin{tabular}{lll}
\hline Region & Monthly MW Rate & Hourly MW Rate \\
\hline $\begin{array}{l}\text { Peninsular } \\
\text { Malaysia }\end{array}$ & RM900 & RM4.33 \\
$\begin{array}{l}\text { Sarawak and } \\
\text { Sabah* }\end{array}$ & RM800 & RM3.85 \\
* Including federal territory of Labuan. &
\end{tabular}

\section{SOME LESSONS LEARNED FROM OTHER COUNTRIES}

Based on a study [6] commissioned by the Ministry of Human Resource, there are some lessons and challenges learned from other countries in implementing minimum wages as discussed below.

- The design, implementation and adjustment of the minimum wages require good quality data, considerable analytical capacity and time-intensive and evidence-based analysis.

In Chile, there was lack of relevant data when the minimum wages was first set almost 50 years ago, which became the stumbling block in determining the most appropriate rate. Only recently, its government begins to collect relevant data to establish solid evidence to draw on in making better decisions. In Hong Kong, preparations were made two years before the law was passed. The labour market conditions were assessed to help in predicting the impact of a minimum wage on different types of workers and companies. It provided relevant information that became the basis for the design and deliberation processes. In Thailand, the National Minimum Wage Secretariat carried out a survey that was used for their impact analysis and various advance preparations.

The respective governments, assisted by their team of experts, need to have the capacity to use the data that are collected as well as the will to use the findings in making appropriate decisions. In Thailand, the provincial wage councils have limited technical capacity in using the analysis of market conditions or the expected impact of their proposed decisions. Therefore, their decisions are rarely based on these analyses. There is also lack of capacity on the part of trade unions or workers representatives to recognize and acquire technical information, hence limited their ability to put their case in the debates for minimum wages. This has caused the decisions to be biased towards the employers, and hence deemed to be bad and unpopular.

- Balance in the bargaining powers of the negotiating parties in the decision-making process.

In Thailand, there were no effective workers' representatives in many provinces to take part in the negotiating process. They are often not sufficiently prepared to follow and contribute to the technical discussion. Only 3 percent of workers are represented by the labour unions and are in a weak position with respect to the employers. Particularly when the decision-making process is decentralized, there are concerns about the ability of some Minimum Wage Council members in the poorest and isolated provinces to understand the data provided by the National Minimum Wage Secretariat. As a result, the public perceives that the final decision on the minimum wage is made by the employers and government with limited input from the workers.

In Korea, the low capacity of the workers representatives was addressed by inviting public interest group from among the NGOs and academics who have technical knowledge and had no vested interest to participate in the negotiations. This public interest group is also invited to be members of the Minimum Wage Council. In Taiwan, the workers complained that they were not fairly represented which led to the Minimum Wage Council to be reconstituted to increase the representation of workers as well as employers. However, there were still complaints on the effectiveness of the workers representatives in the deliberation process.

- Impact of the minimum wage depends on the number of workers that it affects and on how easy it is to evade it.

In Thailand, over 60 percent of its workforce is in the informal sector, which makes it easy for the employers to evade the minimum wage order. In such cases, the minimum wage affects a very small percentage of the labour force earning below the minimum wage rate. Apparently, many companies subcontracted their blue collar workers to avoid the cost of hiring them formally. However, a new law was enforced to give the right to the workers to take action on their employers for not paying them the minimum wage. This is a disincentive to the employers evading from complying with the order.

- Be aware of other policies that interact with the minimum wage policy.

In designing the policy, and defining the level of the wage and its adjustments, the Minimum Wage Council has to be aware of other interacting policies that may fundamentally change the way in which it affects the targeted population. In Hong Kong, for instance, younger workers do not receive the full minimum wage as they are entitled to a subsidy that encourages employers to hire them. In Thailand, informal workers are entitled to social protection benefits. In Malaysia, the disabled are entitled to employment allowance of RM300 per month regardless of their wage level. It is essential to know of other laws or policies that can either complement or negate the minimum wage to maximize the efficiency in the decision-making and minimize evasion.

- Computation and coverage of the minimum wage need to be thorough.

In Chile, there were loopholes regarding inclusion of allowances and gratuities that gave way to employers to circumvent the law. These loopholes had to be closed to prevent the minimum wage policy from becoming ineffective. In Hong Kong, the employers are allowed by their minimum wage law to set rules on rest days and meal breaks, which are not taken well by workers. The workers are now demanding for paid leave and breaks. In Thailand, when the daily minimum wages was established, it was not translated into hourly rate. It has unintentionally excluded the part-time workers. Discussions to modify the law to include them are still unresolved.

- Labour market must be prepared for the implementation of the minimum wage law.

Any implementation or revision of the minimum wage 
needs to be informed in advance to allow the employers time to adjust. Information campaigns are essential at the outset of the minimum wage policy, and employers and employees need to be educated on the process of implementing and enforcing the minimum wage. In Hong Kong, workers began to understand the meaning of the new legislation through mass media campaigns that called on employers and workers to abide by the new law and adjust to the change. The implementation of the minimum wage forced the companies to stop relying on oral agreements and begin to use written contracts and developing new record keeping systems. A large-scale information campaign on new record keeping methods for employers was undertaken.

In Korea, two years were given between the enactment of the Minimum Wage Act and its implementation to enable companies to prepare. Any uncertainty regarding the timing or magnitude of the adjustment will affect how the companies function, and may therefore, creates unnecessary cost. In Thailand, during election campaigns, employers postponed all wage and benefit increases because there was an expectation that minimum wage rates may change after the election. The politicians may oblige under pressure by electorates.

\section{ImPlementation OF THE Minimum WageS}

The Minimum Wage Order 2012 was gazetted on 16 July, 2012 which enforce the implementation of the minimum wage rates on 1 January, 2013 for employers with more than five workers (about $22 \%$ of business establishments), and on 1 July, 2013 for employers employing five and less workers, excluding firms that provide professional services classified under the Malaysian Standard Classification of Occupation (MASCO) like science and engineering, health, teaching, ICT, legal, hospitality, retail and services professionals. Those companies that have problems to restructure to implement the minimum wages can apply for deferment before the deadlines given by the Ministry of Human Resources. The organisations that have more than five employees are generally assumed to be in a better position to implement the minimum wages compared to those that employ fewer workers. All establishments are required to restructure their workers pay before the dates of enforcement. The minimum wage rates are to be reviewed every two years as required by the NWCC Act 2011.

When the minimum wages are enforced, there are bound to be those who are ignorant of this order due to general disinterest to keep up with current issues that are covered in the mass media, and disconnected from their associations. Most business establishments have implemented the minimum wages by restructuring their workers pay that is below and just above the minimum wages rate. Others have revised more extensively to cover higher pay either voluntarily or under pressure from the workers. The restructuring of the workers pay would encourage the employers to restructure work specifications of those affected. To reduce the likelihood to retrench, the employers can engage with their workers to ensure that the companies are sustainable by justifying the higher wage cost with higher productivity. Other employers absorbed some regular cash allowances into the basic pay to comply. In the case of foreign workers, the employers are allowed to absorb some benefits in kind into their basic pay.

There are reported increases and decreases in employment of workers after the implementation of minimum wages especially in some manufacturing and services sectors. As some employers improve their workers productivity to rationalize the increasing wage cost, they may make a few redundant. These redundant workers and new entrants into the local labour force will feed the industries that are highly in need of local workers to a certain extend. This is because there is still a generally low interest among the locals to work in the 3D (dirty, dangerous and demeaning) subsectors, such as logging and plantations. As much as the employers in these subsectors want to employ more locals in their companies, they have to resort to engaging foreign workers instead Nevertheless, there are still a lot of job opportunities in the manufacturing and services sectors that have relied on foreign workers due to limited takers from local workers. Some of the local workers who do not have a permanent job, should realise that they are not competing with the foreigners for a vacancy but rather for their committed and productive services to their employers.

\section{CONCLUSION}

The concept of implementing the minimum wage needs to be understood in order to appreciate the reasons for implementing the national minimum wages. The rationale, objectives, coverage and technical details of its implementation have shown how thorough studies and considerations have been made and carried out before any decision related to it is made. The government has also learned from the experience of other countries and initiatives were taken to avoid problems faced by them. However, managing the implementation of minimum wage is not an easy task. With meticulous preparation for an optimal design of the minimum wage policy, Malaysia is facing its own challenges to ensure that it will be able to achieve the objectives set in the minimum wage policy.

\section{ACKNOWLEDGMENT}

We would like to acknowledge support from Ministry of Human Resource, Malaysia in writing this paper.

\section{REFERENCES}

[1] D. Card and A. B. Krueger, "Minimum wages and employment: A case study of the fast-food industry in New Jersey and Pennsylvania," American Economic Review, vol. 84, no. 4, pp. 772-793, 1994.

[2] D. Neumark and W. Wascher, "Minimum wages and employment: A case of the fast food industry in New Jersey and Pennsylvania," American Economic Review, vol. 90, pp. 1362-1396, 2000.

[3] D. Neumark and W. Wascher, "Employment effects of minimum and subminimum wages: Panel data on state minimum wage laws," Industrial and Labor Relation Review, vol. 47, pp. 497-512, 1994.

[4] D. Levine, "Can Wage Increases Pay for Themselves? Tests with a Productive Function," Economic Journal, vol. 102, no. 414, pp. 1102-1115, 1992.

[5] D. Raff and L. Summers, "Did Henry ford pay efficiency wages?" Journal of Labor Economics, vol. 5, no. 4, pp. 57-86, 1987.

[6] National Wages Consultative Council, The National Minimum Wages (First Report), Ministry of Human Resources, Malaysia, 2012.

[7] M. Ransom, "Seniority and monopsony in the academic labour market," American Economic Review, vol. 83, no. 1, pp. 221-233, 1993.

[8] J. Mincer and L. Leighton, "The effects of minimum wages on human capital formation," in The Economics of Legal Minimum Wages, Simon 
Rottenberg (Ed), Washington DC. The American Enterprise Institute, 1981.

[9] C. Brown, C. Gilroy, and K. Andrew, "The effect of the minimum wage on employment and unemployment," Journal of Economic Literature, vol. 20, no. 2, pp. 487-528, 1982.

[10] J. Trapani and J. R. Moreney, "The impact of federal minimum wages laws on employment of seasonal cotton workers," in The Economics of Legal Minimum Wages, Simon Rottenberg (Ed), Washington DC. The American Enterprise Institute, pp. 233-246, 1981.

[11] D. Neumark and W. Wascher, "Do Minimum Wages Fight Poverty?" Economic Inquiry, vol. 40, no. 3, pp. 315-333, July 2002.

[12] G. Stigler, "The economics of minimum wage legislation," American Economic Review, vol. 36, pp. 358-365, 1946.

[13] World Bank, "Optimal Design for a Minimum Wages Policy in Malaysia," Report commissioned by the Ministry of Human Resources, Malaysia, 2011.

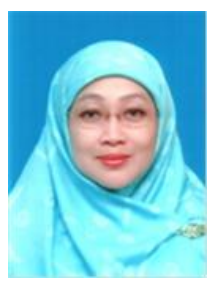

Nurhani Aba Ibrahim is a technical committee member for the National Wage Consultative Council of Malaysian since 2011. The committee is responsible to conduct various studies on labour, wages, and minimum wages and write occasional reports on the implementation of minimum wage in Malaysia. She obtained her PhD in Economics from the University of Leicester, UK (2007), Master of Business Administration from Universiti Teknologi MARA, Malaysia (1999) and Bachelor of Economics (Hons) from the International Islamic University, Malaysia (1992).
She is a Senior Lecturer at the Department of Economics, Faculty of Business Management, Universiti Teknologi MARA (UiTM), Samarahan Campus, Sarawak, Malaysia. She has more than 20 years of teaching experience at the university. She was also a Coordinator for the UiTM-Industry Linkages Centre at the same campus (2009-2011). She had supervised six MSc Finance students at the School of Management, University of Leicester (2005-2006) and currently supervises three $\mathrm{PhD}$ and two master by research students at the Universiti Teknologi MARA. She was the lead researcher for a Fundamental Research Grant Scheme titled "The Causality of Economic Stimulus Packages and Downsizing on the Productivity and Profitability of Manufacturing Firms in Malaysia" which was recently completed in 2013. She has co-authored books, including Strategic Industrialization Programmes and Database for Small and Medium Industries (SMIs) in Sarawak, Volume 1 \& 2, (Sarawak, Malaysia: Ministry of Industrial Development, 1996) and Business and Market Opportunities for Bumiputera Entrepreneurs in Kuching Division, (Sarawak, Malaysia: DUBS, 1995). Her recent article publication is "Causality between Exports and Productivity in the Malaysian Economy" Singapore Economic Review, vol. 56(3), 2011.

Dr. Nurhani is also a panel evaluator (Economics) for the Malaysian Qualifying Agency, member of the Royal Economic Society, Economics Association of Malaysia and Social Science Association of Malaysia. 